A - preparing concepts

$\mathrm{B}$ - formulating methods

C - conducting research

E - interpretation and conclusions

$\mathrm{F}$ - editing the final version
$\mathrm{D}$ - processing results

\section{Urinary incontinence due to chronic disc disease and sciatica}

\author{
Izabela Aleksandra Zawadzka ${ }^{1, A-C}$ (D), \\ Aleksandra Truszczyńska-Baszak ${ }^{1, D-F}$ (D), Katarzyna Jóraszz,D,F*
}

${ }^{1}$ Faculty of Rehabilitation, Józef Piłsudski University of Physical Education in Warsaw, Warsaw, Poland

${ }^{2}$ Faculty of Physical Education, Józef Piłsudski University of Physical Education in Warsaw, Warsaw, Poland

*Correspondence: Katarzyna Jórasz; Józef Piłsudski University of Physical Education, Marymoncka 34, 00-968 Warsaw, Poland; e-mail: katarzyna.krzysztoszek@onet.pl

\title{
Abstract
}

Introduction: Urinary incontinence (UI) is a common health problem, which affects an increasing number of people at any age. This disease influences the physical and mental condition. People who suffer from chronic lumbar pain are more likely to have stress urinary incontinence. The aim of this study was to assess the incidence of involuntary urine leakage among group of patients with lumbar spine disc disease. An additional purpose was to find risk factors of UI in this group.

Material and methods: The study was conducted in the spine surgery department in one of orthopedic hospitals. The study group consisted of adults diagnosed with lumbar spine discopathy with sciatica. The control group included healthy participants. There were 50 subjects in each group.

Results: Based on statistical analysis, there is no significant difference between the study and the control group in the occurrence of urinary incontinence problem. Subjects with UI had a higher level of disability. Almost $74 \%$ people of the study group and $66 \%$ of the control group have never heard about the most popular form of urinary incontinence treatment, which is a pelvic floor muscles training.

Conclusions: 1 . The main risk factors for urinary incontinence in the study group were the nature of the work performed and the sex. Hard physical work significantly increases the risk of UI.

2. The level of knowledge of treatment and prevention of urinary incontinence among participants was very low, therefore there is a need for education in this area.

Keywords: urinary incontinence, disc disease, sciatic neuritis

\section{Introduction}

Urinary incontinence is a disease which affects almost 5 million of Poles. The World Health Organization (WHO) defined it as the one of the most important health problems nowadays. Uncontrolled leakage of urine (for various reasons) makes affected people feel uncomfortable and influences their mental health and social life [1-5].

Urinary incontinence is more common in women than men, due to specific risk factors among women e.g. pregnancy. There are various reasons of UI, therefore there are several types of this disorder. The therapeutic process is determined by the correct diagnosis. 
Stress urinary incontinence is the most common type. It is characterized by the loss of some bladder content when the intra-abdominal pressure increases e.g. sneezing, coughing or running. Pelvic floor abnormalities are considered as the main reason. The dysfunctions of pelvic floor muscles are not only associated with the loss of their strength $[3,5,6]$. According to the International Continence Society (ICS) there are four basic functions of perineum muscles: involuntary contraction, involuntary relaxation, voluntary contraction and voluntary relaxation [7].

The most often recommended pelvic floor strengthening training can be ineffective, when the exercises are not individualized. Pelvic floor muscles examination (palpation, EMG, ultrasound) allows to asses not only their strength, but also other parameters (endurance, trigger points, initial tension, reactivity). This is necessary to determine the appropriate therapeutic procedure [8-11].

An intervertebral disc hernia can also cause sphincter dysfunction due to pressure on nerve structures. The external urethral sphincter is innervated by the pudendal nerve from segments S2-S4, while the internal sphincter sympathetically from segments Th10-L1 [12,13]. Pelvic floor muscles as a group of deep muscles have an important stabilizing function in the feedforward mechanism. Without proper control of local muscles lumbar region can be overloaded and symptoms associated with discopathy may increase [14]. Considering above connections, urinary incontinence and chronic lumbar pain are often related [15-17].

The main purpose of the study was to determine the occurrence of urinary incontinence problem in a group of patients with lumbar discopathy compared to the control group of people without back pain and to define the risk factors of UI. An additional aim was to assess knowledge of prevention and treatment of urinary incontinence in the study and control group.

\section{Material and methods}

The study was approved by the Bioethical Committee at the University of Rzeszow (no. 3/01/2014). The study included 100 adults: 50 hospitalized at the department of spine surgery in Professor Adam Gruca's Independent Public Clinical Hospital in Otwock and 50 subjects in the control group. There were 26 men and 24 women in each group. The study group consisted of participants with lumbar spine discopathy diagnosed by X-ray and MRI, with sciatica and neurological deficits. All subjects from the study group were qualified for surgery - discectomy.

Inclusion criteria for the study group were chronic lumbar pain, sciatica and neurological deficits. Exclusion criteria were other spinal diseases confirmed by $\mathrm{X}$-ray and MRI, urinary and nervous system pathologies and internal problems.

Both groups did not differ statistically significantly in terms of age, weight and body height. Biometric data are presented in the table 1 below.

The study was conducted in the form of an anonymous questionnaire, which contained questions about e.g. professional activity, lumbar pain and urinary incontinence connected problems. The subjects were also asked to assess their knowledge about treatment and prevention of urinary incontinence (very good, good, not much, very low). In addition, the Oswestry Disability Index (ODI) questionnaire was used to assess the degree of disability associated with lumbar pain.

\section{Statistical methods}

STATISTICA 13.1 PL was used to analyze the collected data. The t-student test for independent groups and the chi-square test were performed. A significance level of 0.05 was used in all tests.

\section{Results}

Based on statistical analysis, there was no significant difference between the study and the control group in the occurrence of urinary incontinence problem $(\mathrm{p}=0.8218)$.

Respondents reported the problem of involuntary loss of urine during situation with an increased intraabdominal pressure, which may indicate a stress or mixed type of urinary incontinence (tab. 2).

In both groups, the majority of people with urinary incontinence were women (over 85\%). The groups

Tab. 1. Characteristics of the study and the control group

\begin{tabular}{lcccc}
\hline Group & Study & Control & T & P \\
\hline Body mass [kg] & $83.44 \pm 18.47$ & $77.52 \pm 12.64$ & 1.89 & 0.061 \\
Body height [cm] & $173.83 \pm 10.83$ & $171.02 \pm 8.74$ & 1.45 & 0.150 \\
BMI [body mass $/$ high $^{2}$ ] & $27.58 \pm 4.84$ & $26.68 \pm 4.62$ & 0.96 & 0.337 \\
\hline
\end{tabular}




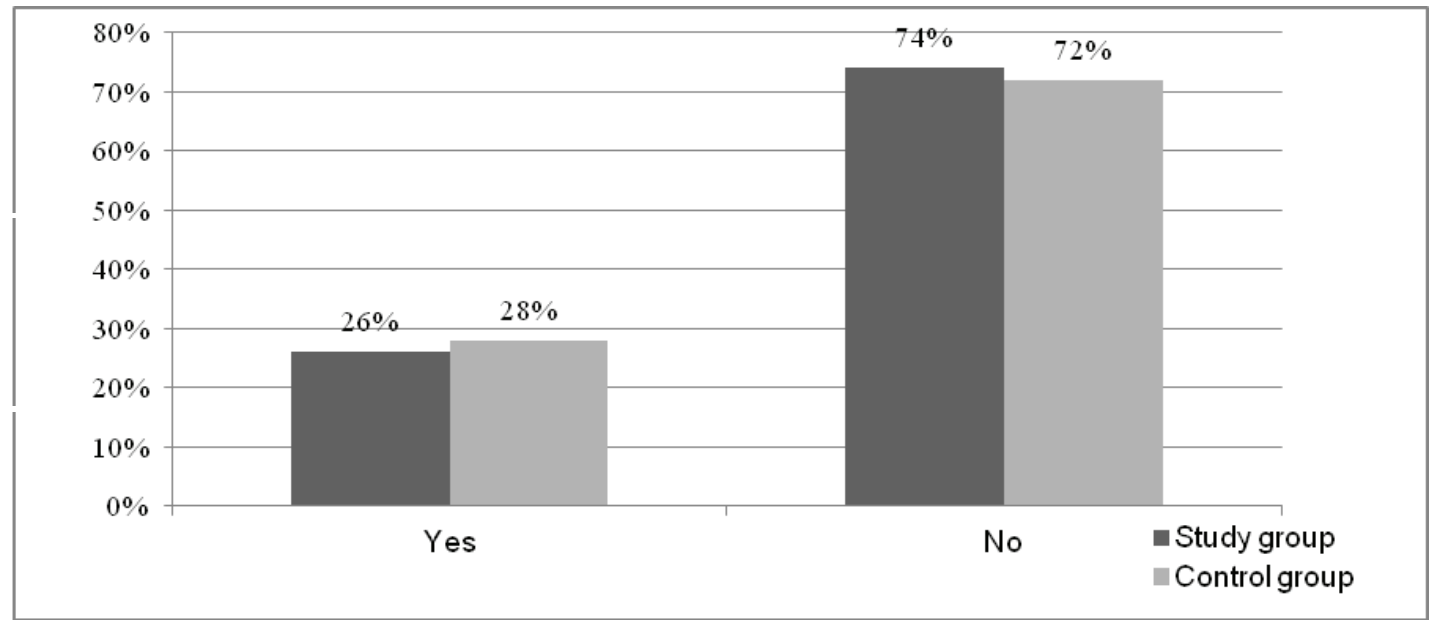

Fig. 1. The occurrence of urinary incontinence in the study and the control group $(p=0.05)$

Tab. 2. Involuntary loss of urine

\begin{tabular}{lcc}
\hline & Study group & Control group \\
\hline Sneezing & $64 \%$ & $93 \%$ \\
Cough & $57 \%$ & $64 \%$ \\
Lifting & $71 \%$ & $36 \%$ \\
Physical activity & $29 \%$ & $29 \%$ \\
Walking & $7 \%$ & $0 \%$ \\
Walking up the stairs & $7 \%$ & $0 \%$ \\
\hline
\end{tabular}

differed significantly in terms of disability level, assessed using ODI. The subjects from the study group showed a higher level of disability than those in control group $(\mathrm{p}<0.0001)$. Moreover, the subjects with urinary incontinence (from both groups), had also a higher level of disability than others.

A statistically significant correlation was found between the level of disability and urinary incontinence in the study and the control group $(p=0.01)$. The subjects with the problem of involuntary leakage of urine in the study group showed a higher level of disability than people in the control group. Urinary incontinence was the most common among subjects with severe $(46 \%)$ and very severe $(31 \%)$ disabilities.

There was also a statistically significant difference in terms of professional activity between the groups. $(\mathrm{p}=0.01)$. Almost $42 \%$ of respondents from the study group had physically heavy work (control group $-16 \%)$. In the control group most subjects performed physically light or mental work $(40 \% ; 38 \%)$. Detailed results are presented in the table 3.

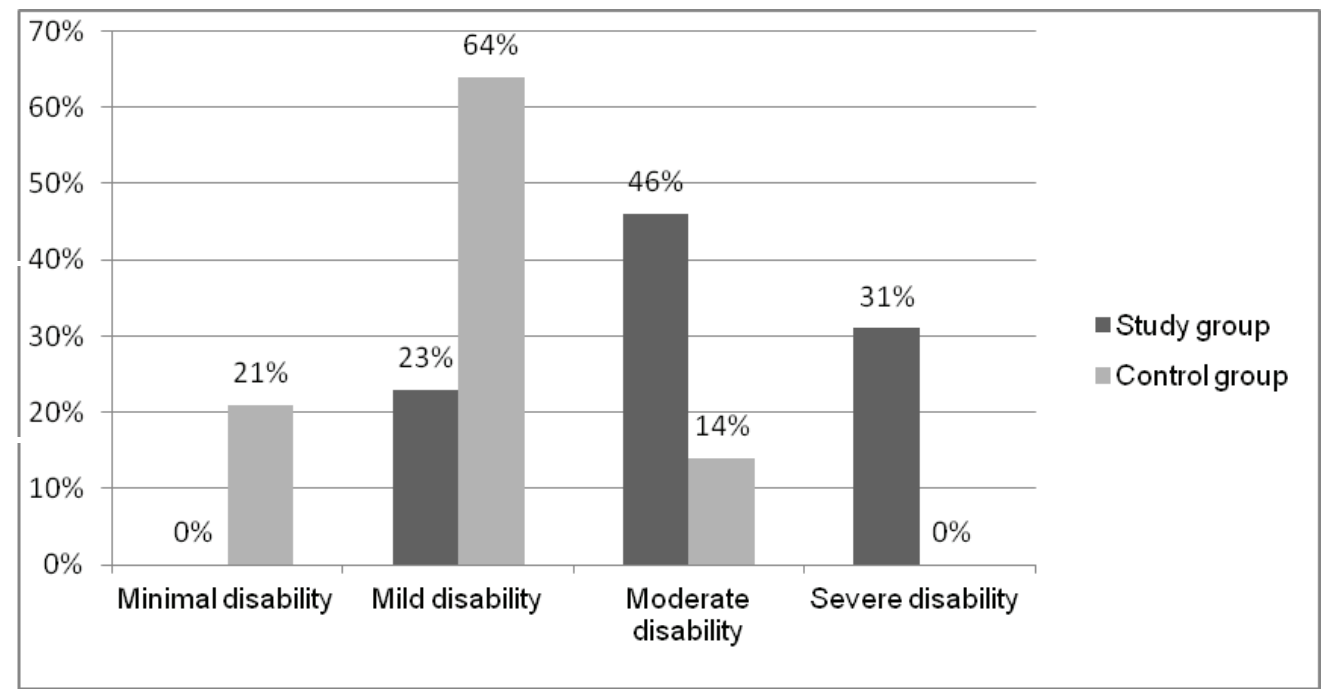

Fig. 2. The comparison of disability level in subjects with UI between groups $(p=0.05)$ 
Tab. 3. The professional activity in each group

\begin{tabular}{lcc}
\hline \multirow{2}{*}{ Proffesional activity } & \multicolumn{2}{c}{ Group } \\
\cline { 2 - 3 } & Study & Control \\
\hline Physicaly light & $34 \%$ & $40 \%$ \\
Physically heavy & $42 \%$ & $16 \%$ \\
Mental & $24 \%$ & $38 \%$ \\
Retirement & $0 \%$ & $6 \%$ \\
Sum & $100 \%$ & $100 \%$ \\
\hline
\end{tabular}

The impact of the nature of work and the BMI level on urinary incontinence was assessed. There was no statistically significant influence of the BMI on the UI. However the impact of occupational activity was noticed $(\mathrm{p}=0.01)$. People performing physically heavy work were significantly more often exposed to have urinary incontinence than people with physically light or mental profession. Data are shown in the figure 3.

All people form the study group with urinary incontinence reported weakened muscular strength of lower extremities (subjective assessment) and had a positive Laseque's test. Using the chi-square test $(p=0.01)$ a positive correlation was found between UI and neurological disorders.

The majority of people with UI in the study and control group considered the problem of involuntary urine loss as embarrassing (study group - 88\%; control group $-95 \%$ ). Despite this, only $10 \%$ of responders in the study group and $6 \%$ in the control group started any treatment in the past. Almost $74 \%$ of participants in the

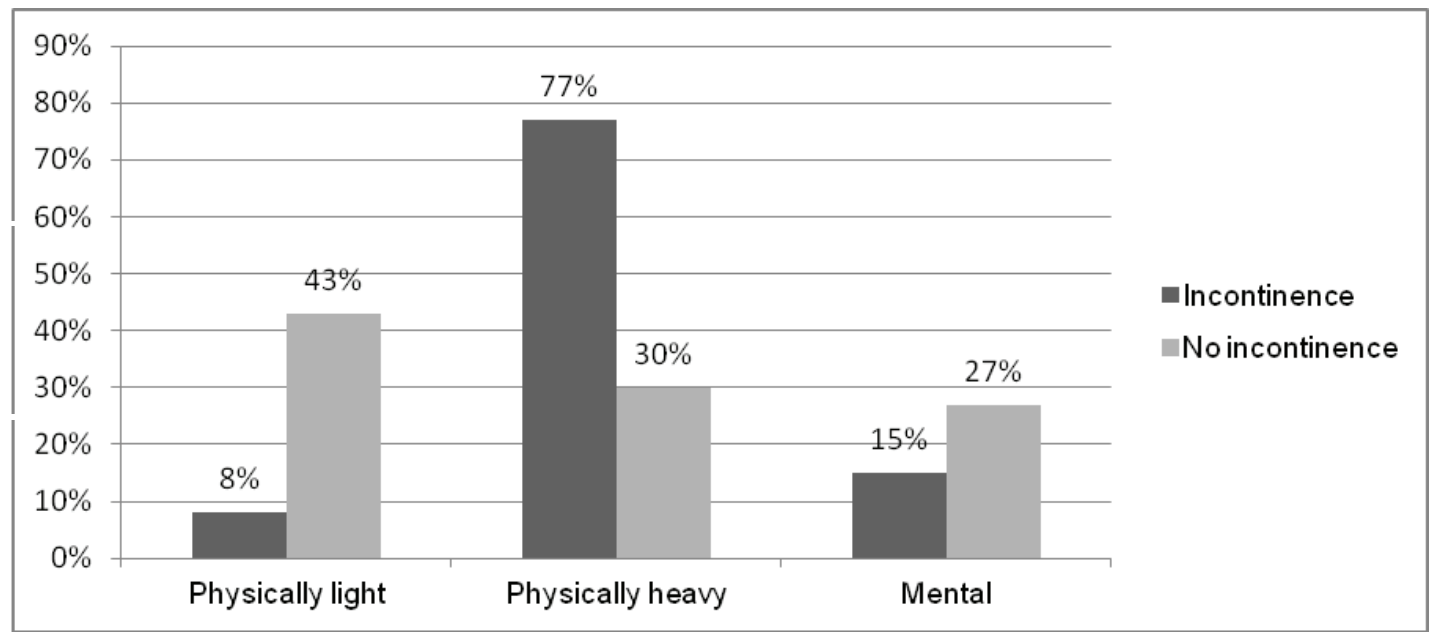

Fig. 3. The influence of occupational activity on the occurrence of urinary incontinence $(p=0.05)$

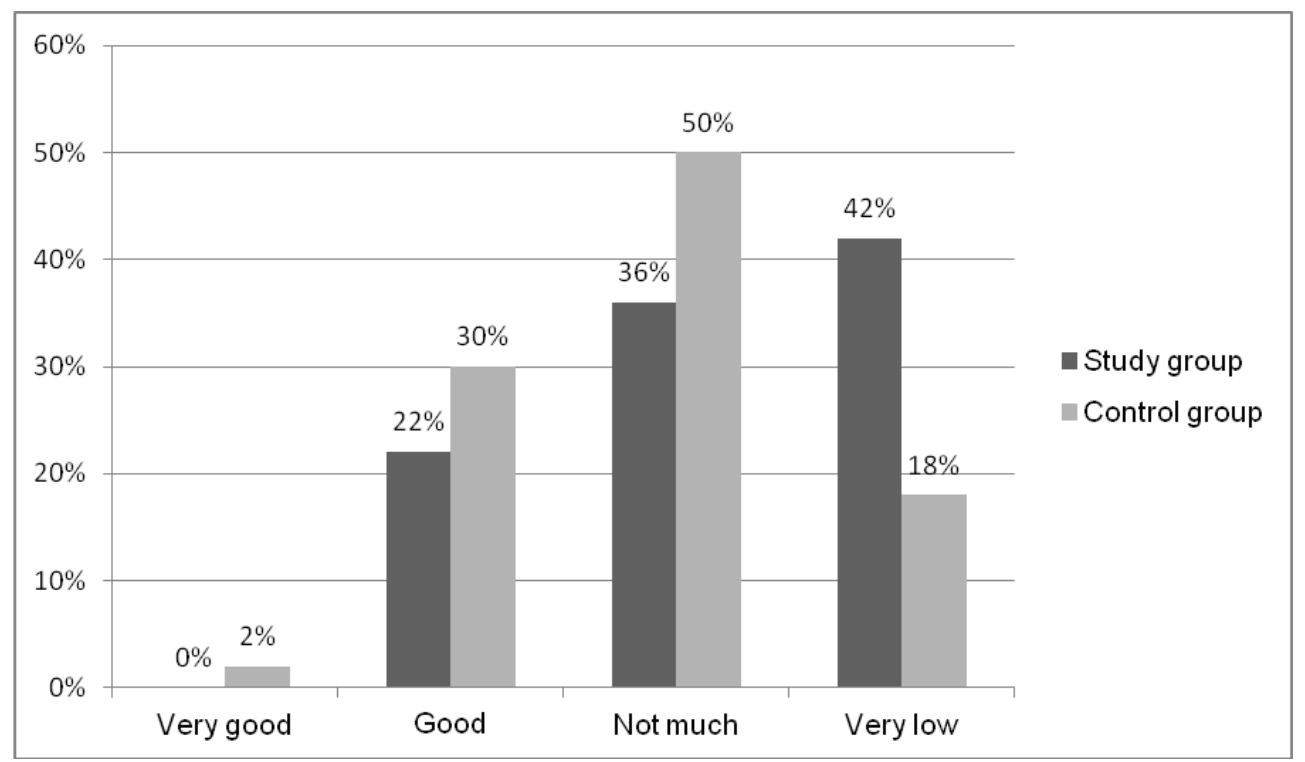

Fig. 4. The level of knowledge about therapy of urinary incontinence in groups $(p=0.05)$ 
study group and $66 \%$ in the control group have never heard about the most popular form of UI treatment, which is pelvic floor muscles training (PFMT).

\section{Discussion}

The low back pain is the most common reason for seeking medical care. It is often chronic, which makes it a social problem, affecting not only the individual, but also the entire society. Each year low back pain affects younger and younger people, limiting their activity. According to the other authors' research, more than half people with chronic lumbar pain have problems with their daily activities $[18,19]$.

In developed countries $50-80 \%$ of the population suffers from low back pain [20]. Poland does not differ statistically from the other European countries. According to statistics, as much as $70 \%$ of the Polish population suffers from chronic back pain, including $44 \%$ with lumbar pain [21].

There are many risk factors of low back pain. Modern lifestyle has a negative influence on the lumbar spine - sedentary work, weak or moderate physical activity, stress, obesity [18]. According to the literature, these factors affect the abdominal and pelvic girdle dysfunctions, disturbing the stabilization of the spine [22].

The conducted research proved, that urinary incontinence often coexists with chronic lumbar pain, especially in women. This is probably the result of the disturbed function of the pelvic floor muscles, which do not only control the lower urinary tract, but also stabilize the pelvic girdle and lumbar spine. The other authors' conclusions are similar [15-17].

In other authors' studies the high BMI level was described as a factor predisposing to stress urinary incontinence [23-25]. This has not been confirmed in this study. According to this research the nature of profession performed significantly affects the occurrence of UI. Physical work, especially hard work has the greatest impact.

Urinary incontinence significantly reduces the quality of patients' life, affects all spheres and limits their physical activity. It increases the feeling of their shame and reduces their desire to socialize. Many patients also require psychological and psychiatric treatment because of involuntary loss of urine. Almost $64 \%$ people with UI have depressive symptoms and only $3.5 \%$ attends specialists [26,27].

It is also surprising that patients are poorly informed about the possibilities of treatment and prevention of urinary incontinence, in spite of the high effectiveness of treatment (e.g. physiotherapy). There is a need to increase the awareness of patients and also medical personnel in this area, as well as preventive action. These conclusions are similar with the results of studies of other authors [28-32].

The conducted research has a practical value. The collected data show the scale of the urinary incontinence problem. It is recommended that medical professionals taking care of patients with chronic lumbar pain also pay attention to this aspect. Conclusions from research should also motivate to carry out preventive programs and launch an educational campaign. It is advisable to continue this research, including physiotherapeutic assessment of pelvic floor muscles (strength, endurance, timing, relaxation skills) in this group of patients. Due to some certain limitations this was not possible in this research.

\section{Conclusions}

1. The nature of the work performed and the sex were the main risk factors for urinary incontinence in the study group. Hard physical work significantly increases the risk of UI.

2. The level of knowledge about treatment and prevention of urinary incontinence among participants is very low, therefore there is a need for education in this area.

\section{Funding}

This research received no external funding.

\section{Conflicts of interest}

The authors declare no conflict of interest.

\section{References}

1. Abrams A, Khoury S, Wein A. Incontinence. Monaco: Health Publication Ltd; 1999.

2. Abrams P, Cardozo L, Fall M, et al. The standardization of terminology of lower urinary tract function: report from the standardization sub- committee of the International Continence Society. Urology. 2003 Jan; 61(1): 37-49.

3. Starczewski A, Brodowska A, Brodowski J. Epidemiologia i leczenie nietrzymania moczu oraz obnizenia narządów miednicy u kobiet. Pol Merk Lek. 2008 Nov; 145: 74-6.

4. Stowarzyszenie URO-CONTI 2016. Wpływ NTM na koszty społeczno-ekonomiczne w Polsce http:// ntm.pl/upload/file/Raport_NTM\%20w\%20Polsce.pdf [dostęp: 12.06.2017].

5. Dobroński P, Radziszewski P, Borkowski A. Nietrzymanie moczu. Med Dypl. 2006 Mar; 3: 37-41. 
6. Bump RC. Discussion: Epidemiology of urinary incontinence. Urol. 1997 Oct; 50: 35-41.

7. Messelink, B, Benson T, Berghmans B, et al. Standardization of terminology of pelvic floor muscle function and dysfunction: report from the pelvic floor clinical assessment group of the International Continence Society. Neurourol Urodyn. 2005 Apr; 24(4): 374.

8. Van Kampen M, De Weerdt W, Fey SH, Honing S. Reliability and validity of a digital test for pelvic muscle strength in women. Neurourol Urodyn. 1996 Jan; 15: 338-9.

9. Slieker-ten Hove MCP, Pool-Goudzwaard AL, Eijkemans MJC, Steegers-Theunissen RPM, Burger CW, Vierhout ME. Face validity and reliability of the first digital assessment scheme of pelvic floor muscle function conform the new standardized terminology of the International Continence Society. Neurourol Urodyn. 2009 Apr; 28(4): 295-300.

10. Santoro GA, Wieczorek AP, Dietz HP, et al. State of the art: an integrated approach to pelvic floor ultrasonography. Ultrasound obstet gynecol. 2011 Apr; 37(4): 381-96.

11. Frawley HE, Dean SG, Slade SC, Hay-Smith I. PelvicFloor Muscle Training a Physical Therapy or a Behavioral Therapy? A Call to Name and Report the Physical, Cognitive, and Behavioral Elements. Phys Ther. 2017 Apr; 97(4): 425-37.

12. Battiě MC, Videman T. Lumbar disc degeneration epidemiology and genetics. J. Bone Joint Surg Am. 2006 Apr; 88(2): 3-9.

13. Sikorski A, Olszewski J, Miekos E. Anatomical considerations of selective pudental neurectomy. Int Urol Nephrol. 1987 Feb; 19(2): 159-63.

13. Comerford M, Mottram S. Kinetic Control: The Management of Uncontrolled Movement. Elsevier; 2012.

14. Ghaderi F, Mohammadi K, Amir Sasan R, Niko Kheslat S, Oskouei AE. Effects of Stabilization Exercises Focusing on Pelvic Floor Muscles on Low Back Pain and Urinary Incontinence in Women. Urology. 2016 Apr; 93: 50-4.

15. Eliasson K, Elfving B, Nordgren B, Mattson E. Urinary incontinence in women with low back pain. Man Ther. 2008 Jun; 13(3): 206-12.

16. Dufour S, Vandyken B, Forget MJ, Vandyken C. Association between lumbopelvic pain and pelvic floor dysfunction in women: A cross sectional study. Musculoscelet Sci Pract. 2018 Apr; 34: 47-53.

17. Kochman D. Jakość życia. Analiza teoretyczna. Zdr Pub. 2007 Feb; 117: 242-8.

18. Klimaszewska K, Krajewska-Kułak E, Kondzior D, Kowalczuk K, Jankowiak B. Jakość życia pacjentów z zespołami bólowymi odcinka lędźwiowego kręgosłupa. Problemy Pielęgniarstwa. 2011 Mar; 19(1): 47-54.

19. Schaofer A, Hall T, Biffa K. Classification of low back-related leg pain. A proposed patho-mechanismbased approach. Man Ther. 2009 Apr; 14: 222-30.

20. Koszewski W. Bóle kręgosłupa. Problemy medyczne i społeczne. In: Koszewski W, editors. Bóle kręgosłupa i ich leczenie. Poznań: Termedia; 2010. p. 11-4.

21. Świerkot J. Bóle krzyża - etiologia, diagnostyka i leczenie. Przew Lek. 2006 Jun; 9: 86-98.

22. Swenson WC, Trowbridge ER, Berger MB, et al. Obesity and stress urinary incontinence in women: compromised continence mechanism or excess bladder pressure during cough? Int Urogynecol J. 2017 Sep; 28(9): 1377-85.

23. Wesnes SL, Rortveit G, Bø K, Hunskaar S. Urinary incontinence during pregnancy. Obstet Gynecol. 2007 Apr; 109: 922-8.

24. Thompson J, Roberts CL, Currie M, Ellwood DAD. Prevalence and persistence of health problems after childbirth: associations with parity and method of birth. Birth. 2002 Nov; 29: 83-94.

25. Stowarzyszenie URO-CONTI, 2019. Raport pacjenta z NTM w systemie zdrowotnym. http://uroconti.pl/ userfiles/file/Raporty/Raport_NTM_2019.pdf [dostęp 17.02.2019]

26. Yip SK, Cardozo L. Psychological morbidity and female urinary incontinence. Best Pract Res Clin Obstet Gynaecol. 2007 Apr; 21(2): 321-9.

27. Lim R, Liong ML, Leong WS, Khan NAK, Yuen KH. Effect of Stress Urinary Incontinence on the Sexual Function of Couples and the Quality of Life of Patients. J Urol. 2016 Jul; 196(1): 153-8.

28. Wong T, Lau BYT, Mak HL, Pang MW, Cheon C, Yip SK. Changing prevalence and knowledge of urinary incontinence among Hong Kong Chinese women. Int Urogynecology J. 2006 Mar; 17(6): 593-7.

29. Derewiecki T, Duda M, Majcher P, Mroczek K. The women's knowledge about urinary incontinence and ways of controlling the illness. Zdr Publ. 2012 Dec; 122(3): 269-73.

30. Szymona-Pałkowska K, Janowski K, Pedrycz A, Mucha D, et al. Knowledge of the Disease, Perceived Social Support, and Cognitive Appraisals in Women with Urinary Incontinence. BioMed Res Int. 2016 Dec; 21.

31. Cygańska AK, Sobieska D, Truszczyńska-Baszak A, Tomaszewski P, Krzysztoszek K. Women's Awareness of Physiotherapeutic Methods in the Treatment of Urinary Incontinence. Adv Rehab. 2018; 4: 21-7. 